\title{
Phenotypic and Genotypic Correlation Coefficient Studies in Tomato (Solanum lycopersicum L.) for Yield and Quality Traits
}

\author{
Ambresh", H.B Lingaiah, M. Renuka and K. Jyothi \\ University of Horticultural Sciences, Bagalkot, Karnataka, India \\ *Corresponding author
}

A B S T R A C T

\begin{tabular}{l} 
K e y w o r d s \\
$\begin{array}{l}\text { Correlation } \\
\text { coefficient, Tomato, } \\
\text { Genotypes, Yield and } \\
\text { quality. }\end{array}$ \\
Article Info \\
$\begin{array}{l}\text { Accepted: } \\
17 \text { September } 2017 \\
\text { Available Online: } \\
\text { 10 November } 2017\end{array}$ \\
\hline
\end{tabular}

Keywords

Correlation

coefficient, Tomato,

Genotypes, Yield and quality.

Accepted:

Available Online:

10 November 2017
Phenotypic and genotypic correlation coefficient studies were carried out in recombinant inbred line population of Vaibhav x Anaga cross for yield and quality characters. The association studies showed that fruit yield/plant $(\mathrm{kg})$ has positive correlation with plant height $(\mathrm{cm})$, Average fruit weight $(\mathrm{g})$, number of branches per plant, number of fruits per plant, total soluble solids and number of locules/fruit at both genotypic and phenotypic levels. However, Average fruit weight has significant and negatively correlated with number of fruits per plant, both at the genotypic and phenotypic levels. Number of branches per plant has significant and negatively correlated with total soluble solids ( ${ }^{0}$ Brix) at both the levels. Hence, direct selection for these traits is done for improving fruit yield per plant.

\section{Introduction}

Tomato (Solanum lycopersicum L.) is a member of the family solanaceae and significant vegetable crop of special economic importance in the horticultural industry worldwide (He et al., 2003). It has a chromosome number of $2 n=24$. Tomato is a native of Peru Equador region it is the most important warm-season fruit vegetable grown throughout the world. Tomato is the most important vegetable crop next only to potato because of its wider adaptability, high yielding potential and multipurpose uses. A crop breeding programme, aimed at increasing the plant productivity requires consideration not only of yield but also of its components that have direct or indirect bearing on yield. Correlation coefficient analysis give an insight into the genetic variability present in populations.

Correlation coefficient analysis measures the mutual relationship between various plant characters and determines the component characters on which selection can be based for improvement in yield. An improvement in yield and quality in self-pollinated crop like tomato is normally achieved by selecting the genotypes with desirable character combinations existing in nature or by hybridization. Information on the nature and extent of variability present in genetic stocks, heritability, genetic advance and interrelationship among various characters is a prerequisite for framing any selection 
program. The phenotypic correlation coefficient and genotypic correlation coefficient and direct and indirect effects were computed.

\section{Materials and Methods}

The present investigation on "Phenotypic and Genotypic Correlation Coefficient Studies in Tomato (Solanum lycopersicum L.) for yield and quality traits" was carried out during the years 2014-15 at College of Horticulture, University of Horticultural Sciences Campus, GKVK, Bengaluru The experimental site is situated at $13^{0}$ North latitude and $77.37^{\circ}$ East longitudes Eastern Dry Zone of Karnataka (Zone-5) The bacterial wilt resistant variety, Anaga and susceptible variety, Vaibhav (Table 1).

The seeds from $F_{1}$ hybrid derived from the cross involving Anagha, bacterial wilt resistant variety released from Kerala Agricultural University and Vaibhav, a bacterial wilt susceptible variety released UAS, Bengaluru were used as starting material to develop recombinant inbred lines (RILs) segregating for bacterial wilt resistance. In a previous study at College of Horticulture, UHS Bengaluru, this cross combination was identified for $F_{1}$ being resistant and productive and a genetic analysis involving these two parents also revealed monogenic/oligogenic nature of inheritance (Jyothi et al., 2013).

A population size of ca. 300 will be maintained starting from $F_{2}$ generation. The $\mathrm{F}_{2}$ lines were maintained at college of Horticulture Bangalore, by selfing $F_{1}$ of the cross Anagha x Vaibhav. All the $\mathrm{F}_{2}$ individual plants of Vaibhav $x$ Anaga were advanced to $F_{3}, F_{4}, F_{5}$ and $F_{6}$ generations following the Single Seed Descent (SSD) method for attaining homozygous and heterogeneous RIL population. Further $\mathrm{F}_{6}$ recombinant inbred lines were studied for correlation coefficient for different characters for yield and quality traits in tomato. Observations were recorded for qualitative and quantitative characters viz., Plant height $(\mathrm{cm})$, number of primary branches, days to $50 \%$ flowering, number of clusters per plant, number of flowers per clusters, days to first fruit set, days to first fruit harvest, number of fruits per clusters, number of fruits per plant, fruit yield per plant $(\mathrm{kg})$ and TSS $\left({ }^{\circ} \mathrm{Brix}\right)$

\section{Results and Discussion}

Simple correlation studies were carried for all the characters studied. Plant height has a significant and positive correlation with average fruit weight (0.591 and 0.532), days to first flowering (0.374 and 0.247), number of branches per plant (0.477 and 0.305), number of fruits per plant (0.231 and 0.198), total soluble solids ( ${ }^{\circ}$ Brix) (0.349 and 0.286 ), number of locules/fruit (0.236 and 0.122), $\mathrm{pH}$ $(0.336$ and 0.240$)$ and fruit yield per plant (kg) (0.569 and 0.382), at both genotypic and phenotypic levels.

Average fruit weight showed significant and positive correlation with number of branches per plant $(0.214$ and 0.164$)$, total soluble solids (0.325 and 0.213), number of locules/fruit (0.189 and 0.144) and fruit yield per plant $(\mathrm{kg})(0.303$ and 0.214$)$, at both genotypic and phenotypic levels. It had significant and negative correlation with number of fruits per plant (-0.317 and -0.264), both at the genotypic and phenotypic levels.

Days to first flowering showed significant and positive correlation with total soluble solids (0.318 and 0.287) and pericarp thickness (mm) (0.275 and 0.166) at both genotypic and phenotypic levels. It had significant and negative correlation with number of locules/fruit (-0.209 and -0.199) and fruit yield per plant $(\mathrm{kg})(-0.350$ and -0.211$)$, both 
at the genotypic and phenotypic levels.

Number of branches per plant had significant and positive correlation with number of fruits per plant (0.194 and 0.148) and fruit yield per plant (0.441 and 0.270), at both genotypic and phenotypic levels. It had significant and negative correlation with total soluble solids ( ${ }^{\circ}$ Brix) (-0.306 and -0.117$)$ at both genotypic and phenotypic levels.

Number of fruits per plant showed significant and positive correlation with total soluble solids ( ${ }^{\circ}$ Brix) (0.276 and 0.182 ) and pericarp thinkness (mm) (0.385 and 0.317), number of locules/fruit (0.331 and 0.294) and fruit yield per plant $(\mathrm{kg})(0.325$ and 0.212$)$ at both genotypic and phenotypic levels.

Total soluble solids had significant and positive correlation with number of locules/fruit (0.443 and 0.324) and fruit yield per plant (0.418 and 0.220$)$, at both genotypic and phenotypic levels. It showed negative correlation for $\mathrm{pH}(-0.271$ and -0.195$)$ at both levels. Number of locules/fruit showed significant and positive correlation with $\mathrm{pH}$ (0.370 and 0.310) and fruit yield per plant (0.396 and 0.280), at both genotypic and phenotypic levels. Pericarp thinkness showed positive correlation with fruit yield per plant (0.236 and 0.181) at both phenotypic and genotypic levels (Table 2 and 3 ).

Yield is the resultant of combined effect of several component characters and environment. Understanding the interaction of characters among themselves and with environment has been of a great use in the plant breeding. Correlation studies provide information on the nature and extent of association between only two pairs of metric characters.

From this it would be possible to bring about genetic upgradation in one character by selection of the other, therefore, knowledge about character associations will surely help to identify the characters to make selection for higher yield with a view to determine the extent and nature of relationship prevailing among yield contributing characters.

Hence, an attempt has been made to study the character association in the tomato accessions at both the levels.

Table.1 The experiment material used for present study

\begin{tabular}{|l|l|l|l|}
\hline Sl.No. & Variety & Source & Salient features \\
\hline 1 & Anaga & KAU, Thrissur & $\begin{array}{l}\text { Determinate growth habit, bacterial wilt } \\
\text { resistant variety with minimum average } \\
\text { fruit weight }\end{array}$ \\
\hline 2 & Vaibhav & UAS, Bengaluru & $\begin{array}{l}\text { Determinate growth habit, Bacterial wilt } \\
\text { susceptible variety }\end{array}$ \\
\hline 3 & $\begin{array}{l}\text { Recombinant inbred } \\
\text { line population (RILP) }\end{array}$ & COH Bangalore & $\begin{array}{l}\text { Population developed for correlation } \\
\text { studies }\end{array}$ \\
\hline
\end{tabular}


Table.2 Genotypic correlation coefficients of yield related traits of recombinant inbred line populations of Vaibhav x Anaga cross

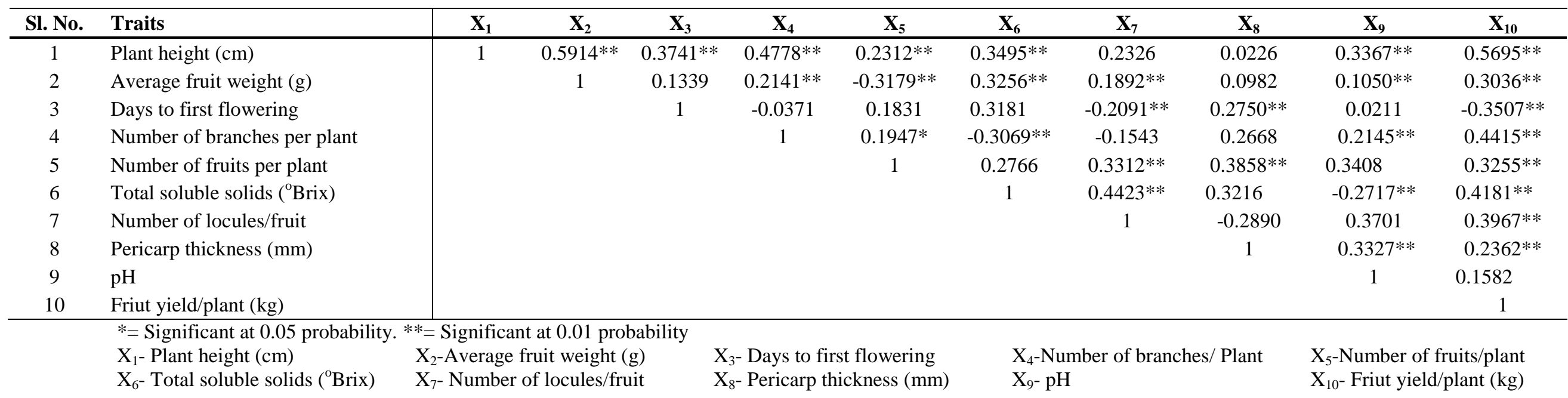

Table.3 Phenotypic correlation coefficients of yield related traits in recombinant inbred lines of Vaibhav x Anaga cross

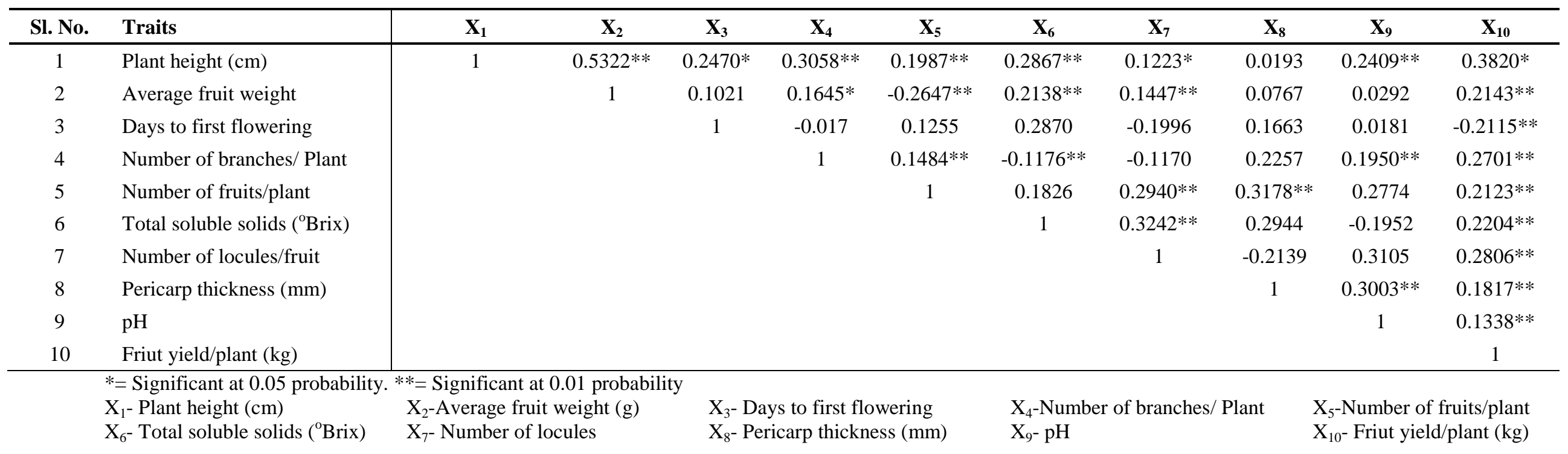


The genotypic correlation was higher than the phenotypic correlations in the present study indicating high heritable nature of the characters. Also the result showed that there was not much difference between genotypic and phenotypic correlation among characters studied. This indicates that the influence of environment is least on correlation. However, one can be closer to their selection based on phenotypic values. In the present study, yield and yield components were investigated and their relationship with fruit yield per plant as well as among themselves was determined using correlation analysis.

Plant height had significant and positive correlation with average fruit weight, number of branches per plant, number of fruits per plant, Similar result were observed by Mohanty (2002), Raut et al., (2005), Patil (1998), and Mayavel et al., (2005). It had significant and positive correlation with fruit yield per plant. These results are in conformity with the findings of Aravindakumar and Mulge (2002), Tiwari and Krishnamoorthy (2002), Lakshmikant and Mani (2004), Mayavel et al., (2005) and Raut et al., (2005).

Average fruit weight showed significant and positive correlation with number of branches per plant, number of locules and fruit yield per plant at both genotypic and phenotypic levels. Similar finding were observed by Dhankhar et al., (2001) and Singh (2005). It had significant and negatively correlated with number of fruits per plant. These results are in conformity with the findings of Sidhu and Singh (1989) and Joshi et al., (2004).

Days to first flowering showed significant and positive correlation with total soluble solids and pericarp thickness at both genotypic and phenotypic levels. It had significant and negatively correlated with number of locules and fruit yield per plant, similar finding were observed by Singh (2005) both at the genotypic and phenotypic levels.

The character, number of fruits per plant had high positive significant correlation with fruit yield per plant at both genotypic and phenotypic levels. Direct selection of genotype based on such characters. Therefore, selection for any of these highly associated characters with fruit yield per plant will indirectly help in selecting the plants with high yield. Hence, it is worthwhile to have genotypes with higher number of fruits per plant to get higher yields. Similar results were observed by Aravindakumar and Mulge (2002), who also noticed positive association of number of fruits per plant with fruit yield per plant.

Number of branches per plant had significant positive correlation with number of number of fruits per plant, apart from number of branches per plant. These related traits showed significant positive association among themselves. Hence, selection for any of these traits would improve the other traits. These results suggested that the number of branches can advantageously be used as criteria for selection.

The association and cause effect studies showed that fruit yield per plant was positively and significantly correlated with number of fruits per plant. High direct effects are also observed for these traits. So, by improving these traits yield can be significantly increased.

\section{References}

Aravindakumar, J. S. and Mulge, R., 2002, Influence of environments on association of yield and its components traits in tomato (Lycopersicon esculentum Mill.). Veg. Sci., 29(1): 2729. 
Dhankhar, S. K., Dhankar, B. S. and Sharma, N. K., 2001, Correlation and path analysis in tomato under normal and high temperature conditions. Haryana J.Hort. Sci., 30(1-2): 89-92.

He, C., Poysa, V. and Yu, K. 2003. Development and characterization of simple sequence repeat (SSR) markers and their use in determining relationships among Lycopersicon esculentum cultivars. Theoretical Applied Genetics, 106: 363-373.

Joshi, A., Vikram, A. and Thakur, M. C., 2004, Studies on genetic variability, correlation and path analysis for yield and physico-chemical traits in tomato. Prog. Hort., 36(1): 51-58.

Lakshmikant and Mani, 2004, Association and contribution of different characters towards fruit yield in tomato (Lycopersicum esculentum Mill.) in north western hill zone. Indian J. Hort., 61(4): 327-330.

Mayavel, A. Balakrishnamuthy, G. AND Natarajan, S., 2005, Variability and heritability studies in tomato hybrids. South Indian Hort., 53(1-6): 262-266.

Mohanty, B. K., 2002, Variability, heritability, correlation and path coefficient studies in Tomato. Haryana J. Hort. Sci., 31(3\&4): 230-233.

Raut, R. L., Naidu, A. K. and Jain, P. K., 2005, Correlation study in tomato (Lycopersicon esculentum Mill.). South Indian Hort., 53(1-6): 258-261.

Sidhu, A. S. and Singh, S., 1989, Genetic variability and correlation for yield and quality characters in tomato (Lycopersicon esculentum Mill.). Indian J. Agric. Sci., 59(12): 810-812.

Singh, A. K., 2005, Genetic variability, correlation and path coefficient studies in tomato (Lycopersicon esculentum Mill.) under cold arid region. Prog. Hort., 37(2): 437-443.

Tiwari, G. C. and Krishna Moorthy, P. N., 2002, Yield loss in tomato caused by fruit borer. Indian J. Agric. Sci., 54(4): 341-343.

\section{How to cite this article:}

Ambresh, H.B Lingaiah, M. Renuka and Jyothi, K. 2017. Phenotypic and Genotypic Correlation Coefficient Studies in Tomato (Solanum lycopersicum L.) for Yield and Quality Traits. Int.J.Curr.Microbiol.App.Sci. 6(11): 2287-2292.

doi: https://doi.org/10.20546/ijcmas.2017.611.271 